attention than the animal. But it is physiological in the widest sense, encroaching, as occasion arises, on physics, on bio-chemistry, on botany and zoology, and on histology. At the present time there are no workers at the Institute other than the staff and the scholars, but it is the hope and desire of the founder that it may be frequented by students from all parts of the world, who are assured beforehand of a hearty welcome and of a hospitable reception.

The foundation of the Research Institute in Calcutta, as well as of the branch, Mayapuri, situated at Darjiling at $7000 \mathrm{ft}$. elevation, in an altogether different climate, was due, in the first instance, to the munificence of Sir J. C. Bose; since then, considerable sums have been contributed by Indian princes and others for extensions and for endowment. The Imperial Government of India has recognised the value of the services rendered by the Institute to the advancement of science by making an annual grant out of public funds for its upkeep. The Institute has continued from the beginning to expand both materially and intellectually. It has shown what important results can be obtained by the combination of the logic and the scientific methods of the West with the imagination and the idealism of the East. Even now it is still only at the beginning of its career, a career, let us hope, of everincreasing usefulness and brilliance, which ought to be assured by the principles of self-abnegation upon which its constitution is based, more than fulfilling the most sanguine expectations of its founder and reviving the ancient reputation of India as a home of learning.

\title{
The Lewis Evans Collection at Oxford.
}

\section{Recent AdDitions.}

W HEN the oldest of British museums was re opened for the scientific treasures presented to the University of Oxford by Dr. Lewis Evans, it was foreseen that that fine collection must act as a lodestone and attract cognate objects to itself. This expectation has been realised in a remarkable measure by gifts and loans of apparatus, and by the discovery and reconstruction of long-forgotten instruments. The first fruits of the reversion of a part of the Old Ashmolean building to its original use as a Science Museum are now on exhibition.

Several colleges have contributed apparatus that is second to none for illustrating the early history of many scientific inventions. Both Merton and Oriel Colleges have proved themselves faithful custodians of the quadrants and astrolabes of their astronomer-fellows of the fourteenth century. No other educational institution can boast continuous possession of scientific appliances for so many centuries. Contemporary manuscripts written about these very instruments, describing their use, collected when the instruments to which they refer were three centuries old, were given by Ashmole to be "preserved in the presses" of his Science Museum, that his good name might endure "for all time." There they remained for yet another two hundred years, while the instruments, to the use of which they supplied the key, languished in college chests and cupboards. To-day the instruments are on exhibition in Ashmole's building, while Ashmole's own books about them have been put away out of sight in hidden recesses in buildings other than those named in his will. If both books and instruments were once again placed side by side, we should have visible proof of the scientific pre-eminence of the Merton School in the fourteenth century.

To a distinguished fellow of Merton we owe the beginning of our technical scientific literature. Richard, the son of a blacksmith at Wallingford, received a practical education that enabled him in 1326 to compose in terms as clear as those of a proposition of Euclid, a model treatise, the first of its kind known to have been written by an Englishman, upon "How to Make" a scientific instrument. He prescribed the exact dimensions of the metal parts, both in the rough and in the finished state; and he illustrated the shaping and fitting by working diagrams, so that it is possible to interpret his meaning after six hundred years. His distinction as a man of science led to ecclesiastical preferment. Richard, the maker of our first recorded astronomical clock, became abbot of St. Albans. His ' rectangulus,' figured in NATURE for January I2, I924, has been partly reconstructed this very year in honour of the sixth centenary of his original invention.

Two centuries later the needs of Elizabethan navigators and gunners advanced the skill of the instrument maker to higher levels, both of execution and of invention. By the generosity of the University Court of St. Andrews, there is on view the finest astrolabe known to have been made by an English craftsman. It is 2 feet in diameter, and 33 pounds in weight. It is inscribed with the name of its maker, Humphrey Cole of London, and is dated with the day of the month, May $2 \mathrm{I}, 1575$, the very year when he was getting ready the instrumental outfit for Martin Frobisher's first expedition in search of the North-west Passage to Cathay, an enterprise in which Elizabeth herself was financially interested to the extent of roool. By the finding of Cole's great astrolabe we have proof for the first time that there were in London craftsmen capable of executing work equal in quality to that of the instrumental equipment of the best-endowed observatory in the world, the astronomical observatory of Tycho Brahe at Uraniborg. Nor was this Cole's only claim to a place in our memory. He was the first Englishman to engrave a copperplate map for the illustration of a book, the Bishops' Bible of $x_{572}$. The advent of the Lewis Evans collection has also led to the discovery of one of Cole's early theodolites in the Library of St. John's College. This discovery proves him to have been the maker and improver, if not the original designer, of our premier surveying instrument, an invention usually associated with the name of Leonard Digges of University College.

A century later and we come to the epoch of the great experimenters, too soon to be followed by the epoch of the great destroyers. The Royal Society, finely equipped in the days of Daniel Colwall and Grew

$$
\text { NO. 296I, VOL. I I 8] }
$$


with a repository of scientific apparatus that would now have the utmost historical value, has neglected and scattered the instruments of its great alumni, Boyle, Wren, Hooke. A fashion has been set of undervaluing scientific treasures left in trust, the latest examples being the dispersal of the Crisp collection of Microscopes, of the Howard Library (by the Royal Society), and of a part of the Library of Sir Isaac Newton.

The Lewis Evans collection has afforded an opportunity of trying to stem the current of our losses, and by the construction of models illustrating certain aspects of the work of the first Oxford fellows of the Royal Society. Models of Wren's perspectograph and level recall his method of dealing with problems presented by the devastated areas in the Metropolis after the Great Fire of I666. A model of Hooke's microscope recalls what was perhaps the greatest achievement of that universally inventive genius, the first discovery of cell structure in living beings. In another case is an exhibit illustrating the first discovery of oxygen in 1668 by John Mayow of Wadham College. A model of Boyle's first airpump reminds us that it was the High Street in Oxford that produced the first English engine to demonstrate the possibility of harnessing the force exerted by atmospheric pressure, the "spring of the air," as Boyle called it. Other models show how the dwellers in an inland town have been able to teach and assist navigators; Hooke's reflecting instrument, Gunter's cross-staff and sector, the magnetic compasses of I269 of Peter Peregrinus, and of $175^{\circ}$ of Gowin Knight of Magdalen College being notable examples, paralleled in our own time by the instruments invented for seamen by Lord Kelvin.

Space will not permit us to rehearse all the exhibits in our small Museum, but in truth we may define it as a school of gratitude to the great men who have increased the knowledge and the power of the human race. The most recent of the reconstructions is a beautifully made astrolabe designed by Prof. Frewen Jenkin, for making known the virtues and uses of that 'mathematical jewel' to a wider public than the favoured few who possess original examples. In this regenerated form, the astrolabe again becomes an instrument of great educational value.

The enterprise of museum founding has not been without its disappointments. First and foremost was the dispersal of the collection formed by Sir Frank Crisp to illustrate the evolution of the microscope.
Through the kindness of Sir John Findlay, one of the masterpieces of that collection, a superb silver instrument by Adams, is on view in Oxford for the meeting of the British Association. But the general disappearance of much good apparatus in Oxford itself is deplorable. Only a few months ago there were in existence things of great scientific interest which have vanished. A model with which Bradley illustrated his discovery of the aberration of light is not now forthcoming. Antique microscopes, barometers, the paraphernalia of the educational methods of a century of preparation for the great scientific advances of to-day, have gone to the scrap heap-destroyed in many cases by the urgent needs of research in hand. In the modern laboratory there is no place in which to store the apparatus of bygone experimenters, even if there were a desire to keep it intact, rather than to make use of its parts.

It is our plea that scientific instruments that are of value, either for beauty of design, for achievement in the laboratory or lecture-room, or for some other good cause, should at least be treated with the respect that is accorded to early editions of printed books in a library, or to pictures in a gallery of art. The destruction of a copy of an old book that has been printed in hundreds and reprinted in tens of thousands, inflicts no great harm on the world of letters, but the loss of a unique instrument obscures the whole meaning of early work. Only by contemporary scientific appliances can we hope to show to future generations the ever-varying fashions and phases of our natural philosophy: and few objects are better worth the effort, for in our northern civilisation, natural science has become of greater consequence than art. To traverse the long galleries of the museums of arts and crafts, and to study their masterpieces, is a dispiriting pilgrimage, for it brings home to one how slight is the influence that such exhibitions exercise in elevating the art of a modern people. Scientific instruments, too, show regression in respect of their art; but they show continuous advance in respect of their science.

All work of preservation is of the utmost value in that it helps to check a tendency to destroy evidences of our own early civilisation, and to remind us that with our now diminished resources, instead of spending large sums on the conservation of relics of antiquity abroad, it may pay better to honour the prophets of our own country.
R.T. G.

\section{The Oxford Meeting of the British Association.}

$\mathrm{M}^{\mathrm{H}}$ MBERS of the British Association visiting Oxford during the forthcoming meeting will find themselves in the midst of a south-midland district which is, from the naturalist's point of view, possessed of great and varied interest. Opportunities will be given by means of sectional excursions for gaining such acquaintance as may be possible with the geology of the surrounding country, and with noteworthy features of its characteristic fauna and flora. It is obvious that no extended study of the district can be undertaken in the short time at the disposal of those attending the meeting, but the "Handbook" which will be distributed to all visiting members of the Association will provide them with a summary, under various heads, of what the neighbourhood of Oxford can show in the way of natural features of interest.

This handbook, the work of several authors, each of them a first-rate authority on the subject with which he deals, is being produced under the editorship of Commander J. J. Walker, R.N., and will no doubt take rank as a volume of permanent value. It begins with an account by Mr. H. O. Beckit, director of the School of Geography, of the physiography of the Oxford region, including a definition of its boundaries, and describing its land forms and physical history. Sections are added by Mr. W. G. Kendrew on its climate, by 